\title{
PENGARUH PERTUMBUHAN EKONOMI DAN KETIMPANGAN PENDAPATAN TERHADAP JUMLAH KEMISKINAN DI PROVINSI NUSA TENGGARA BARAT (NTB)
}

\author{
${ }^{1}$ Wira Hendri, ${ }^{2}$ Taufan Iswandi, \\ Fakultas Keguruan dan Ilmu Pendidikan (FKIP) Universitas Gunung Rinjani \\ Email: wirahendri@gmail.com
}

\begin{abstract}
Abstrak
Penelitian ini bertujuan menganalisis pengaruh pertumbuhan ekonomi dan ketimpangan pendapatan terhadap pengentasan kemiskinan di provinsi Nusa Tenggara Barat. Variabel penelitian yang digunakan dalam penelitian ini adalah variabel pertumbuhan ekonomi, ketimpangan pendapatan dan jumlah penduduk miskin di provinsi Nusa Tenggara Barat. Jenis data yang digunakan dalam penelitian ini data kuantititatif dalam bentuk data panel dengan rentang waktu Januari $2018 \mathrm{~s} / \mathrm{d}$ Desember 2020. Sumber data diperoleh dari BPS. Metode penulisan menggunakan regresi berganda dalam bentuk logaritma. Hasil analisis menyimpulkan Variabel pertumbuhan ekonomi berpengaruh signifikan terhadap perkembangan jumlah penduduk miskin di provinsi Nusa Tenggara Barat disebabkan kontribusi dari dana perimbangan yang mendominasi perekonomian di NTB mencapai hampir 70 persen dari total pendapatan daerah sehingga pembangunan ekonominya masih ditarik oleh pemerintah pusat.

Variabel ketimpangan pendapatan tidak berpengaruh signifikan terhadap jumlah penduduk miskin di provinsi Nusa Tenggara Barat. signifikannya ketimpangan pendapatan terhadap jumlah penduduk miskin disebabkan program pembangunan yang dilakukan pemerintah daerah kurang merata disetiap daerah terutama di daerah pedesaan.
\end{abstract}

Kata kunci: Pertumbuhan ekonomi, ketimpangan pendapatan, jumlah penduduk miskin dan regresi berganda

\begin{abstract}
This study aims to analyze the effect of economic growth and income inequality on poverty alleviation in the province of West Nusa Tenggara. The research variables used in this study are the variables of economic growth, income inequality and the number of poor people in the province of West Nusa Tenggara. The type of data used in this study is quantitative data in the form of panel data with a time span of January 2018 to December 2020. The data source is obtained from BPS. The writing method uses multiple regression in the form of logarithms. The results of the analysis conclude that the variable economic growth has a significant effect on the development of the number of poor people in the province of West Nusa Tenggara due to the contribution of the balancing fund that dominates the economy in NTB reaching almost 70 percent of total regional income so that economic development is still drawn by the central government.

The income inequality variable has no significant effect on the number of poor people in the province of West Nusa Tenggara. The significant inequality of income towards the number of poor people is due to the development programs carried out by local governments that are not evenly distributed in each region, especially in rural areas.
\end{abstract}

Keywords: Economic growth, income inequality, number of poor people and multiple regression 


\section{PENDAHULUAN}

Pembangunan ekonomi pada hakekatnya bertujuan untuk meningkatkan kesejahteraan masyarakat, dalam rangka meningkatkan kesejahteraan masyarakat maka diperlukan pertumbuhan ekonomi yang meningkat dan distribusi pendapatan yang lebih merata. Peningkatan dan pertumbuhan perekonomian daerah akan membawa pengaruh terhadap peningkatan kesejahteraan rakyat di daerah (Raswita \& Made, 2013).

Ketimpangan pembangunan antara daerah yang satu dengan daerah yang lainnya berdampak pada keseimbangan perputaran kegiatan ekonomi yang berpengaruh pada ketimpangan kemakmuran antar daerah yang bersangkutan. Tambunan (2001) menyatakan terkonsentrasinya kegiatan ekonomi pada suatu daerah tertentu secara langsung berdampak pada ketimpangan pandapatan antar daerah sehingga tercipta kondisi dimana daerah yang menjadi pusat konsentrasi kegiatan ekonomi akan lebih mampu memberikan pendapatan yang lebih tinggi kepada masyarakatnya sehingga masyarakatnya relatif lebih makmur, sementara disisi lain daerah yang bukan merupakan pusat kegiatan ekonomi hanya mampu memberikan pendapatan yang rendah sehingga berakibat relatif rendah pula kemakmuran masyarakatnya.

Menurut Adelman dan Morris (1973) secara umum yang menyebabkan ketidakmerataan distribusi pendapatan di negara sedang berkembang adalah pertambahan penduduk yang tinggi yang mengakibatkan menurunnya pendapatan perkapita, inflasi yang dikarenakan pendapatan uang bertambah tetapi tidak diikuti secara proporsional dengan pertambahan produksi barang-barang, ketidakmerataan pembangunan antar daerah, capital intensif sehingga persentase pendapatan modal dari harta tambahan lebih besar dibandingkan persentase pendapatan yang berasal dari kerja sehingga pengangguran bertambah, rendahnya mobilitas sosial, kebijakan industri substitusi impor yang berakibat pada peningkatan harga barang hasil industri, memburuknya nilai tukar bagi negara sedang berkembang dengan negara maju, dan hancurnya industri-industri kerajinan rakyat, dan lain-lain (Arsyad, 2004).
Pertumbuhan ekonomi, ketimpangan pendapatan, dan kemiskinan adalah isu-isu yang selalu menarik untuk dipelajari. Para ahli mencurahkan perhatian yang cukup besar terhadap hal ini (Lin, 2003; Bourguignon, 2004; Ravalion, 2005; danWarr, 2000, 2006 dalam Wijayanto, 2016). Pertumbuhan ekonomi yang tinggi akan memperbesar kapasitas ekonomi (Produk Domestik BrutoPDB). Diharapkan dengan PDB yang tinggi maka akan tercipta trickle down effect sehingga kesejahteraan masyarakat akan meningkat. Isu tentang pertumbuhan ekonomi, ketidakmerataan pendapatan dan kemiskinan telah lama menjadi fokus utama pembangunan ekonomi baik di tingkat global maupun nasional. Analisa hubungan segitiga antara ketiga hal tersebut telah menjadi bahan perdebatan yang panjang dan sangat menarik terutama pada pemilihan strategi pembangunan ekonomi dalam upaya pengentasan kemiskinan. Pertama, apakah lebih mendahulukan pertumbuhan ekonomi yang tinggi dengan mengesampingkan pembagian distribusi pendapatan. Kedua, apakah lebih mengutamakan distribusi pendapatan yang lebih merata tanpa harus mengorbankan pertumbuhan ekonomi. Di sisi lain, adanya permasalahan kemiskinan dan ketidakmerataan pendapatan juga akan menghambat laju pertumbuhan ekonomi itu sendiri. Selain itu, kemiskinan dan ketidakmerataan pendapatan juga akan memberikan dampak instabilitas sosial, ketidakpastian, dan tragedi kemanusiaan seperti kelaparan, tingkat kesehatan yang rendah dan gizi buruk. Bila keadaan tersebut terus berlanjut pada akhirnya akan mengganggu stabilitas ekonomi makro dan kelangsungan pemerintahan yang ada. Menurut Arsyad (1999) dalam Hajiji (2010) tingkat pertumbuhan ekonomi yang tinggi hanya sedikit manfaatnya dalam memecahkan masalah kemiskinan, masih banyak penduduk yang memiliki pendapatan dibawah standar kebutuhan hidupnya. Pertumbuhan ekonomi gagal untuk mengurangi bahkan menghilangkan besarnya kemiskinan absolut. Jadi pertumbuhan PDB yang cepat tidak secara otomatis meningkatkan taraf hidup masyarakatnya. Dengan kata lain bahwa apa yang disebut dengan "Trickle Down Effects" atau efek cucuran kebawah dari manfaat pertumbuhan 
ekonomi bagi penduduk miskin tidak terjadi seperti apa yang diharapkan bahkan berjalan cenderung sangat lambat.

Kesenjangan pembangunan ekonomi antar kabupaten/kota di Propinsi Nusa Tenggara Barat berdasarkan data PDRB antar
kabupaten/Kota dapat dilihat dari nilai PDRB antar kabupaten/kota berbeda-beda dan selama tiga tahun terakhir nilai PDRB tiaptiap kabupaten/kota mengalami peningkatan. Hal tersebut dapat dilihat dari tabel berikut:

Tabel 1.1 PDRB Provinsi NTB berdasarkan harga konstan 2010

\begin{tabular}{lccc}
\hline \multirow{2}{*}{ Kabupaten/kota } & \multicolumn{3}{c}{ PDRB } \\
\cline { 2 - 4 } & 2018 & 2019 & 2020 \\
\hline Kabupaten Lombok Barat & 15313 & 15676 & 14368 \\
Kabupaten Lombok Tengah & 12685 & 13088 & 12112 \\
Kabupaten Lombok Timur & 11557 & 12014 & 11565 \\
Kabupaten Sumbawa & 22005 & 22878 & 21750 \\
Kabupaten Dompu & 19461 & 20053 & 19160 \\
Kabupaten Bima & 16321 & 16853 & 16112 \\
Kabupaten Sumbawa Barat & 89405 & 86040 & 108014 \\
Kabupaten Lombok Utara & 15030 & 15779 & 14486 \\
Kota Mataram & 27398 & 28377 & 26331 \\
Kota Bima & 16973 & 17505 & 16317 \\
\hline
\end{tabular}

Sumber: Badan Pusat Statistik NTB

Berdasarkan pada tabel 1.1 diatas, selama tiga tahun berturut-turut kabupaten sumbawa barat menempati posisi tertinggi jumlah PDRB dibandingkan kabupaten lainnya di NTB. Kemudian disusul oleh kota Mataram dan Kabupaten sumbawa. Sementara, terendah adalah lombok timur. Perbedaan tingkat pembangunan yang ditunjukkan dengan perbedaan nilai PDRB akan membawa dampak perbedaan tingkat kesejahteraan antar daerah yang pada akhirnya menyebabkan ketimpangan regional antar daerah semakin lebar serta dapat menghambat pembangunan ekonomi daerah.

\section{TINJAUAN PUSTAKA}

\section{Pertumbuhan Ekonomi}

Nafziger (2006) menyatakan bahwa pertumbuhan ekonomi adalah peningkatan produksi suatu negara atau pendapatan per kapita. Produksi tersebut dihitung dengan GNP (Gross National Product - Produk Nasional Bruto) atau GNI (Gross National Income - Pendapatan Nasional Bruto) yang merupakan total output dari negara tersebut. Pertumbuhan ekonomi berarti juga peningkatan kapasitas perekonomian suatu wilayah dalam suatu waktu tertentu. Konsep
PDB digunakan pada tingkat nasional, sedangkan untuk tingkat provinsi dan kabupaten/kota digunakan konsep PDRB. PDB atau PDRB dapat diukur dengan 3 macam pendekatan, yaitu pendekatan produksi, pendekatan pendapatan dan pendekatan pengeluaran (Tambunan, 2003). Pendekatan produksi dan pendekatan pendapatan adalah pendekatan dari sisi penawaran agregat (Aggregate Supply - AS) sedangkan pendekatan pengeluaran adalah pendekatan dari sisi permintaan agregat (Aggregate Demand - AD).

Menurut Adam Smith (ahli ekonomi klasik), ada dua aspek utama pertumbuhan ekonomi yaitu (1) pertumbuhan output (GDP) total dan (2) pertumbuhan penduduk. Kedua aspek tersebut berkaitan satu sama lainnya. Berkaitan dengan pertumbuhan output total, Smith melihat sistem produksi suatu negara terdiri dari tiga unsur pokok yaitu sumber daya alam yang tersedia, sumber daya manusiawi (jumlah penduduk) dan stok barang kapital yang ada. Sumbersumber alam yang tersedia merupakan wadah yang paling mendasar dari kegiatan produksi suatu masyarakat. Jumlah sumber-sumber alam yang tersedia merupakan batas maksimum bagi pertumbuhan perekonomian 
tersebut. Artinya, selama sumber-sumber ini belum sepenuhnya dimanfaatkan, yang memegang peranan dalam proses produksi adalah dua unsur produksi yang lain, yaitu jumlah penduduk dan stok kapital yang ada.

Menurut Kuznets dalam Todaro (2004), pertumbuhan ekonomi (economic growth) adalah kenaikan kapasitas dalam jangka panjang dari negara yang bersangkutan untuk menyediakan berbagai barang ekonomi kepada penduduknya. Kenaikan kapasitas di tentukan oleh adanya kemajuan atau penyesuaian-penyesuaian teknologi, institusi (kelembagaan), dan ideologis terhadap berbagai tuntutan keadaan yang ada. Selain itu, Todaro (2003) menyatakan ada 3 faktor dalam pertumbuhan ekonomi di setiap negara yakni; (1) Akumulasi modal (capital accumulation), meliputi semua jenis investasi baru yang ditanamkan pada pabrik baru, tanah, peralatan fisik dan pembagian sumber daya manusia juga dapat meningkatkan kualitasnya, sehingga pada akhirnya akan membawa dampak positif yang sama terhadap angka produksi. Akumulasi modal terjadi apabila sebagian dari pendapatan diinvestasikan kembali dengan tujuan memperbesar output atau pendapatan pada masa yang akan datang; (2) Pertumbuhan penduduk (growth in population) maksudnya adalah dengan pertumbuhan penduduk diikuti oleh pertumbuhan tenaga kerja sebagai salah satu faktor positif yang memacu pertumbuhan ekonomi. Ini berarti dengan pertambahan penduduk akan menambah jumlah produktifitas. Pertumbuhan penduduk yang lebih besar akan menyebabkan pertumbuhan pasar domestik menjadi lebih besar, namun positif atau negatifnya pertumbuhan penduduk dalam pembangunan ekonomi sepenuhnya tergantung pada kemampuan sistem perekonomian tersebut untuk menyerap setiap tambahan angkatan kerja; (3) Kemajuan teknologi (technological progress) merupakan sumber pertumbuhan ekonomi yang paling penting, karena dengan kemajuan teknologi akan ditemukan cara baru ataupun teknologi baru untuk menggantikan cara-cara lama sehingga dapat meningkatkan pertumbuhan ekonomi dengan cepat.

\section{Ketimpangan Pendapatan}

Ketimpangan pendapatan adalah suatu kondisi dimana distribusi pendapatan yang diterima masyarakat tidak merata. Ketimpangan ditentukan oleh tingkat pembangunan, heterogenitas etnis, ketimpangan juga berkaitan dengan kediktatoran dan pemerintah yang gagal menghargai property rights (Glaeser, 2006). Alesina dan Rodrik (1994) menyatakan bahwa ketimpangan pendapatan akan menghambat pertumbuhan. Hal ini karena ketimpangan menyebabkan kebijakan redistribusi pendapatan yang tentunya akan mahal. Todaro dan Smith (2006) menyatakan bahwa ketimpangan pendapatan akan menyebabkan beberapa hal, antara lain:

1. Ketimpangan pendapatan yang ekstrim akan menyebabkan inefisiensi ekonomi.

2. Ketimpangan pendapatan yang ekstrim akan melemahkan stabilitas sosal dan solidaritas.

3. Ketimpangan pendapatan yang ekstrim umumnya dianggap tidak adil.

\section{Kemiskinan}

Kemiskinan tidak hanya berkenaan dengan tingkat pendapatan, tetapi juga dari aspek sosial, lingkungan bahkan keberdayaan dan tingkat partisipasinya, sebagaimana digambarkan oleh World bank (2000) dalam Harniati (2007) mendefinisikan kemiskinan sebagai berikut: "Poverty is hunger. Poverty is lack of shelter. Poverty is being sick and not being able to go to school and not knowing to know how to read. Poverty is not having a job, poverty is fear for the future, living one day at a time. Poverty is powerlessness, lack of representation and freedom ". Menurut Badan Pusat Statistik (BPS) penduduk yang tidak mampu memenuhi kebutuhan dasar minimum dikategorikan sebagai penduduk miskin. Nilai garis kemiskinan yang digunakan mengacu pada kebutuhan minimum 2.100 kkal per kapita per hari ditambah dengan kebutuhan minimum non makanan yang merupakan kebutuhan dasar seseorang yang meliputi kebutuhan dasar untuk papan, sandang, sekolah, transportasi, serta kebutuhan rumahtangga dan individu yang mendasar lainnya. Besarnya nilai pengeluaran (dalam rupiah) untuk memenuhi kebutuhan dasar minimum makanan dan non 
makanan tersebut disebut garis kemiskinan (BPS, 2007).

\section{METODE PENELITIAN}

\section{Lokasi dan Waktu Penelitian}

Penelitian ini mengambil lokasi di Provinsi Nusa Tenggara Barat selama kurun waktu 2018 - 2020, menganalisis tentang keterkaitan pertumbuhan ekonomi, ketimpangan pendapatan dan pengentasan kemiskinan.

\section{Identifikasi variabel penelitian}

Identifikasi variabel didasarkan atas kajian teoritis dan empiris sebagai acuan kerangka berpikir yang terdiri dua variabel, yaitu:

1) Variabel eksogen adalah variabel yang mempengaruhi operasi dalam suatu model ekonomi dan variabel tersebut tidak dipengaruhi oleh setiap hubungan yang digambarkan dalam model tersebut. Variabel eksogen dalam studi ini adalah PDRB (Y) dan ketimpangan Pendapatan $(\mathrm{G})$.

2) Variabel endogen adalah variabel yang dipengaruhi oleh variabel eksogen. Variabel endogen dalam studi ini jumlah Penduduk miskin (P)

\section{Definisi Operasional Variabel}

Dalam upaya mempermudah pelaksanaan penelitian, terlebih dahulu didefinisikan indikator operasional yang terkandung dalam obyek penelitian sehingga variabel yang akan dianalisis dapat dibedakan sebagai berikut :

1. Produk domestik Regional Bruto (PDRB) adalah jumlah nilai tambah bruto yang dihasilkan seluruh unit usaha dalam wilayah tertentu, atau merupakan jumlah nilai barang dan jasa akhir yang dihasilkan oleh seluruh unit ekonomi di Provinsi Nusa Tenggara Barat dan seluruh kabupaten/kota yang ada didalamnya. PDRB disimbolkan dengan $Y$ dalam persentase.

2. Pertumbuhan Ekonomi, Pertumbuhan ekonomi di Provinsi Nusa Tenggara Barat diukur melalui laju pertumbuhan produk domestik regional bruto (PDRB) Provinsi Nusa Tenggara Barat dan seluruh kabupaten/kota yang ada didalamnya. Pertumbuhan ekonomi adalah gambaran dari pertumbuhan total PDRB yang dihitung atas dasar harga konstan tahun 2000, yaitu perbandingan antara nilai PDRB pada satu tahun dengan tahun sebelumnya, dalam persen.

\section{Ketimpangan Pendapatan.}

Ketimpangan pendapatan merupakan ukuran untuk menilai perbedaan jumlah pendapatan yang diterima masyarakat sehingga mengakibatkan perbedaan pendapatan yang lebih besar antar golongan dalam masyarakat tersebut. Ketimpangan pendapatan dalam penelitian ini menggunakan gini rasio kabupaten kota di NTB

\section{Kemiskinan.}

Kemiskinan di Provinsi Nusa Tenggara Barat dan kabupaten/kota yang ada didalamnya diukur melalui jumlah penduduk miskin. Jumlah penduduk miskin dilambangkan dengan $P$ dalam satuan jiwa.

\section{Metode Pengumpulan Data \\ Jenis Data dan Sumber Data}

Jenis Data yang digunakan dalam penelitian ini merupakan data sekunder dengan bentuk data panel. Data panel adalah gabungan dari data time series dan cros section. Sumber data diperoleh dari Badan Pusat Statistik Provinsi Nusa Tenggara Barat. Data yang digunakan antara lain data PDRB, data Gini Rasio dan data jumlah penduduk miskin Provinsi Nusa Tenggara Barat, Periode yang diteliti mulai tahun 2018 sampai dengan 2020.

\section{Variabel Penelitian}

Penelitian ini menggunakan variabel pertumbuhan ekonomi di proksi produk domestik regional brutoi, ketimpangan pendapatan diproksi ke Gini Rasio, jumlah penduduk miskin.

\section{Metode Analisis}

Analisis dalam penelitian ini ditujukan untuk menjawab permasalahan yang dikemukakan terdahulu yaitu untuk menganalisis keterkaitan antara pertumbuhan ekonomi, ketimpangan pendapatan dan kemiskinan di Provinsi Nusa Tengga Barat. Sebagai alat pengolahan data menggunakan software Eviews 4.1 yang menghasilkan output analisis deskriptif. 
Vol. 10. No. 1. Tahun 2022

\title{
Model Analisis
}

$\begin{array}{lllll}\log \mathrm{P} & \alpha & \beta_{1} \log \mathrm{Y} & \beta_{2} \log \mathrm{G} & \varepsilon\end{array}$

dimana :

$P$ : jumlah penduduk miskin (dalam satuan jiwa)

\section{ANALISIS DATA DAN PEMBAHASAN}

\section{Analisis Data}

\section{Regresi Berganda}

Hasil olahan data jumlah kemiskinan menggunakan sofware eviews 4.1 dapat dilihat pada Tabel 4.1 berikut ini :

Tabel 4.1 Hasil Olah Data Eviews

Dependent Variable: LOG KEMISKINAN

Method: Panel Least Squares

Date: $12 / 13 / 21$ Time: $14: 43$

Sample: 20182020

Cross-sections included: 10

Total panel (balanced) observations: 30

\begin{tabular}{lrlll}
\hline \hline \multicolumn{1}{c}{ Variable } & Coefficien & & & \\
\multicolumn{1}{c}{$\mathrm{t}$} & & Std. Error & t-Statistic & Prob. \\
\hline \hline \multicolumn{1}{c}{ LOG PDRB } & -0.859056 & 0.198487 & -4.328017 & 0.0002 \\
\multicolumn{1}{c}{ LOG GINI RASIO } & -1.895938 & 1.347733 & -1.406761 & 0.1709 \\
\hline \hline R-squared & 0.421334 & Mean dependent var & 4.018262 \\
Adjusted R-squared & 0.378470 & S.D. dependent var & 0.781263 \\
S.E. of regression & 0.615926 & Akaike info criterion & 1.963259 \\
Sum squared resid & 10.24284 & Schwarz criterion & 2.103378 \\
Log likelihood & -26.44888 & F-statistic & 9.829524 \\
Durbin-Watson stat & 2.059680 & Prob(F-statistic) & 0.000621 \\
\hline \hline
\end{tabular}

Sumber: Olah data Eviews

Berdasarkan tabel olah data diatas didapat persamaan regresi linier berganda $\log \mathrm{P}=10.55291-0.859056 \mathrm{Y}-1.895938 \mathrm{G}$ + e dengan interpretasinya sebagai berikut : $\mathrm{a}=11.14367$ artinya jika PDRB dan Gini Rasio nol persen maka jumlah penduduk miskin sebesar 10.55291 persen.

$\beta_{1}=-0.859056$ artinya jika PDRB naik satu persen maka jumlah penduduk miskin menurun sebesar -0.859056 persen dengan asumsi gini rasio ceteris paribus.
$Y$ : PDRB konstan (dalam satuan Rp juta)

$G$ : indeks Gini (nilainya antara 0 dan 1)

$\alpha$ : intercept (fixed/random effect untuk kabupaten i)

$\varepsilon$ : error term

$\mathrm{t}: 2018$ sampai dengan 2020

\begin{abstract}
nggunakan sofware eviews 4.1 dapat dilihat
\end{abstract}


Hal tersebut dapat diketahui dengan membandingkan $t_{\text {hitung }}$ dengan $t_{\text {tabel }}$. Apabila $t_{\text {hitung }}<\mathrm{t}_{\text {tabel }}$ atau $\mathrm{t}_{\text {hitung }}>\mathrm{t}_{\text {tabel }}$ maka PDRB berpengaruh signifikan terhadap jumlah penduduk miskin. Sebaliknya, Apabila $t_{\text {tabel }}<$ $t_{\text {hitung }}<t_{\text {tabel }}$ maka PDRB tidak berpengaruh signifikan terhadap jumlah penduduk miskin. Berdasarkan tabel olah data diatas nilai thitung PDRB $=-4.328017>\mathrm{t}_{\text {tabel }}=-1,96$ menujukkan variabel PDRB berpengaruh signifikan terhadap jumlah penduduk miskin di provinsi Nusa Tenggara Barat.

Variabel

ketimpangan pendapatan/gini rasio berpengaruh negatif namun tidak signifikan terhadap jumlah penduduk miskin di NTB. Hal tersebut dapat diketahui berdasarkan nilai $t_{\text {tabel }}=-1,96<$ $\mathrm{t}_{\text {hitung }}=-1.406761<\mathrm{t}_{\text {tabel }}=1,96$.

\section{Uji $F$}

Uji simultan pada tabel olah data diatas menunjukkan bahwa PDRB dan ketimpangan pendapatan/gini rasio secara bersama-sama berpengaruh signifikan terhadap jumlah penduduk miskin di NTB $(0.000<0.05)$.

\section{Koefisien Determinasi $\left(R^{2}\right)$}

Variasi pembentukan jumlah penduduk miskin dalam model penelitian dijelaskan oleh variabel PDRB dan ketimpangan pendapatan sebesar 37,84 persen sedangkan sisanya 62,16 persen dijelaskan oleh faktor lain yang tidak masuk ke dalam model penelitian seperti kelembagaan dalam masyarakat, budaya dan tradisi dan lainlainnya.

\section{PEMBAHASAN}

Berdasarkan hasil analisis data dapat diketahui variabel pertumbuhan ekonomi berpengaruh signifikan terhadap jumlah penduduk miskin di provinsi Nusa Tenggara barat. Hal ini dapat diketahui dari nilai $t_{\text {hitung }}$ $=-4.328017>\mathrm{t}_{\text {tabel }}=1,96$. signifikannya pertumbuhan ekonomi di NTB masih didorong dari kontribusi dari dana perimbangan yang mendominasi perekonomian di NTB. Hal ini dapat diketahui dari tingginya ketergantungan daerah terhadap dana bantuan dari pusat. Berdasarkan hasil analisis kontribusi dana perimbangan terhadap daerah menunjukkan selama periode 2018 s/d 2020 besarnya ketergantungan daerah dalam mambiaya pembangunan mencapai hampir 70 persen sehingga pembangunan ekonominya masih ditarik oleh pemerintah pusat.

Variabel ketimpangan pendapatan tidak berpengaruh signifikan terhadap jumlah penduduk miskin di provinsi Nusa Tenggara Barat. Hal ini dapat diketahui dari nilai nilai $\mathrm{t}_{\text {tabel }}=-1,96<\mathrm{t}_{\text {hitung }}=-1.406761<\mathrm{t}_{\text {tabel }}=$ 1,96. Tidak signifikannya ketimpangan pendapatan terhadap jumlah penduduk miskin disebabkan program pembangunan yang dilakukan pemerintah daerah kurang merata disetiap daerah terutama di daerah pedesaan.

\section{KESIMPULAN}

Berdasarkan analis data dan pembahasan diatas dapat disimpulkan sebagai berikut:

1. Variabel pertumbuhan ekonomi berpengaruh signifikan terhadap jumlah penduduk miskin di provinsi di Provinsi Nusa Tenggara Barat disebabkan kontribusi dari dana perimbangan yang mendominasi perekonomian di NTB mencapai hampir 70 persen dari total pendapatan daerah sehingga pembangunan ekonominya masih ditarik oleh pemerintah pusat.

2. Variabel ketimpangan pendapatan tidak berpengaruh signifikan terhadap perkembangan jumlah penduduk miskin di NTB. Hal ini disebabkan program pembangunan yang dilakukan pemerintah daerah kurang merata disetiap daerah terutama di daerah pedesaan.

\section{DAFTAR PUSTAKA}

Adelman, Irma., and Cynthia T.Morris. (1973). Economic Growth and Social Equity in Developing Countries. Stanford : Stanford University Press.

Arsyad, Lincolin. (2004). Ekonomi Pembangunan (Edisi 4). Yogyakarta: STIE YKPN.

BPS. (2013). NTB Dalam Angka. NTB : BPS

BPS. (2007). Statistik Keuangan Indonesia.

Raswita, Ngakan Putu Mahesa Eka., dan Made Suyana Utama. (2013). 
Analisis Pertumbuhan Ekonomi dan Ketimpangan Pendapatan Antar Kecamatan Di Kabupaten Gianyar 2013. E-Jurnal EP Unud, 2 [3] : 119128

Tambunan, Tulus. (2001). Perekonomian Indonesia: Beberapa Masalah Penting. Jakarta : Ghalia Indonesia Erlangga.

Wijayanto. (2016). Analisis keterkaitan Pertumbuhan Ekonomi, Ketimpangan Pendapatan dan Pengentasan Kemiskinan di Provinsi Sulawesi Utara. Jurnal Berkala Ilmiah Efisiensi Vol. 16 No. 02 Tahun 2016.

Todaro, Michael P. (2003). Pembangunan Ekonomi Di Dunia Ketiga. Alih Bahasa: Aminuddin dan Drs.Mursid. Jakarta: Ghalia Indonesia

Todaro, Michael P. (2004). Pembangunan Ekonomi Di Dunia Ketiga. Edisi Kedelapan. Jakarta: Erlangga.

Sukirno, S. (1985). Ekonomi PembangunanProses, Masalah dan Dasar Kebijakan. LP3ES-UI dengan Bina Grafika, Jakarta Sutarno, 2002. Pertumbuhan ekonomi dan ketimpangan PDRB Per kapita Antar
Kecamatan di Kabupaten Banyumas 1993-2000. Tesis. Program Pasca sarjana UGM, Yogyakarta.

Ravallion M. 2006. Why has economic growth been more pro poor in some states. Journal of Development Economic. Washington DC : World Bank.

Hull, Katy. 2009. Understanding the Relationship between Economic Growth, Employment and Poverty Reduction. US : OECD

Dewanto, Pendi. et al. (2014). Analisis pengaruh pertumbuhan ekonomi dan ketimpangan pendapatan terhadap Pengentasan kemiskinan di kawasan mebidangro. Jurnal Ekonom, Vol 17, No 3, Juli 2014

Fan, Cindy C. (1995). Of Belt And Ladders : State Policy And Uneven Regional Development In Post- Map China. Annals of the association of American geographer, vol.18 No. 3 PP. 421-449.

Galbraith, James K., and Hyunsub Kum. (2012). Inequality and Economic Growth: Data Comparisons and Econometric Tests. UTIP Working Paper Number 21 